\title{
CORRIGENDUM
}

\section{The tumour-suppressor scribble dictates cell polarity during directed epithelial migration: regulation of Rho GTPase recruitment to the leading edge}

LE Dow, JS Kauffman, J Caddy, K Zarbalis, AS Peterson, SM Jane, SM Russell and PO Humbert

Oncogene (2007) 26, 5692; doi:10.1038/sj.onc.1210639

\section{Correction to:}

Oncogene (2007) 26, 2272-2282. doi:10.1038/sj.onc.1210016; published online 9 October 2006

Since publication of the above manuscript, the authors found that Dr K Zarbalis had not been included in the list of authors. The list is correctly shown on this page.

Dr Zarbalis is affiliated with Department of Neurology, University of California, San Francisco, CA, USA.

\section{ERRATUM}

\section{TMPRSS2:ERG gene fusion associated with lethal prostate cancer in a watchful waiting cohort}

F Demichelis, K Fall, S Perner, O Andrén, F Schmidt, SR Setlur, Y Hoshida, J-M Mosquera, Y Pawitan, C Lee, H-O Adami, LA Mucci, PW Kantoff, S-O Andersson, AM Chinnaiyan, J-E Johansson and MA Rubin

Oncogene (2007) 26, 5692; doi:10.1038/sj.onc.1210630

\section{Correction to:}

Oncogene (2007) 26, 4596-4599. doi:10.1038/sj.onc.1210237; published online 22 January 2007
Owing to a typesetting error, the abbreviation ERG was incorrectly expanded in the abstract and text on the first page. The correct expansion for the gene ERG is 'etsrelated gene'. 